\title{
Continuing professional education: motivations and experiences of health and social care professional's part- time study in higher education. A qualitative literature review
}

DOI:

10.1016/j.ijnurstu.2016.08.011

Document Version

Accepted author manuscript

Link to publication record in Manchester Research Explorer

Citation for published version (APA):

Burrow, S., Mairs, H., Pusey, H., Bradshaw, T., \& Keady, J. (2016). Continuing professional education: motivations and experiences of health and social care professional's part-time study in higher education. A qualitative literature review. International Journal of Nursing Studies, 63, 139-145. https://doi.org/10.1016/j.jinurstu.2016.08.011

\section{Published in:}

International Journal of Nursing Studies

\section{Citing this paper}

Please note that where the full-text provided on Manchester Research Explorer is the Author Accepted Manuscript or Proof version this may differ from the final Published version. If citing, it is advised that you check and use the publisher's definitive version.

\section{General rights}

Copyright and moral rights for the publications made accessible in the Research Explorer are retained by the authors and/or other copyright owners and it is a condition of accessing publications that users recognise and abide by the legal requirements associated with these rights.

\section{Takedown policy}

If you believe that this document breaches copyright please refer to the University of Manchester's Takedown Procedures [http://man.ac.uk/04Y6Bo] or contact uml.scholarlycommunications@manchester.ac.uk providing relevant details, so we can investigate your claim.

\section{OPEN ACCESS}




\section{Accepted Manuscript}

Title: Continuing professional education: motivations and experiences of health and social care professional's part-time study in higher education. A qualitative literature review

Author: Simon Burrow Hilary Mairs Helen Pusey Timothy Bradshaw John Keady

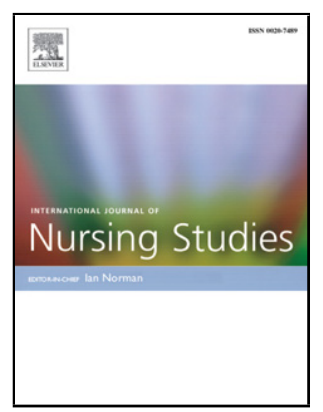

PII: S0020-7489(16)30128-6

DOI:

Reference: http://dx.doi.org/doi:10.1016/j.ijnurstu.2016.08.011

To appear in:

Received date: $\quad 25-4-2016$

Revised date: 22-7-2016

Accepted date: $\quad$ 17-8-2016

Please cite this article as: Burrow, Simon, Mairs, Hilary, Pusey, Helen, Bradshaw, Timothy, Keady, John, Continuing professional education: motivations and experiences of health and social care professional's part-time study in higher education.A qualitative literature review.International Journal of Nursing Studies http://dx.doi.org/10.1016/j.ijnurstu.2016.08.011

This is a PDF file of an unedited manuscript that has been accepted for publication. As a service to our customers we are providing this early version of the manuscript. The manuscript will undergo copyediting, typesetting, and review of the resulting proof before it is published in its final form. Please note that during the production process errors may be discovered which could affect the content, and all legal disclaimers that apply to the journal pertain. 
Continuing professional education: motivations and experiences of health and social care professional's part-time study in higher education. A qualitative literature review

Title:

\title{
Continuing professional education: motivations and experiences of health and social care professional's part-time study in higher education. A qualitative literature review
}

\author{
Authors: \\ Simon Burrow, Hilary Mairs, Helen Pusey, Timothy Bradshaw, John Keady \\ School of Nursing, Social Work and Midwifery, University of Manchester, Oxford Road, Manchester M13 9PL, UK \\ Email addresses: simon.burrow@manchester.ac.uk, hilary.j.mairs@manchester.ac.uk, \\ t.bradshaw@manchester.ac.uk, helen.pusey@mancjhester.ac.uk, john.keady@manchester.ac.uk
}

Words: 5,875

Abstract

Objectives:

To understand the motivations and experiences of health and social care professionals undertaking part-time, accredited, continuing professional education in higher education

Design:

A review following systematic principles

Data Sources: Systematic searches for literature published between January 2000 and December 2015 using the database: SCOPUS, Web of Science, Medline, PsychINFO, Social Policy and Practice and CINAHL.

Review methods:

Studies were included if they were published in the English language and were qualitative in design, focussing on the motivations and experiences of staff engaged in part-time, accredited, higher education study. Three reviewers appraised the quality of the selected studies.

Results:

Thirteen qualitative studies were identified for the review. Motivating factors for staff to engage in part-time, accredited, continuing professional development study included: personal and professional drivers, influence of workplace/management and funding and availability. Key themes in relation to how staff experienced study included: the demands of adjusting to the academic requirements of higher education study; the experience of juggling competing demands of study, work and family; and the presence or absence of support for part-time study in the personal and professional arenas.

Conclusions:

Health and social care professionals experience a number of challenges when engaging in part-time, continuing professional education in higher education institutions. A significant challenge is the juggling of competing demands of study, work and family, and this may have a negative impact on learning. Research is needed to inform how higher education can address the specific learning needs of this population and develop pedagogic approaches that are both responsive to need and support of effective learning. 
Continuing professional education: motivations and experiences of health and social care professional's part-time study in higher education. A qualitative literature review

Key words:

continuing professional education; continuing professional development; health and social care education; higher education; part-time study; post registration education; nursing education 
Continuing professional education: motivations and experiences of health and social care professional's part-time study in higher education. A qualitative literature review

\section{Background}

Continuing professional development (CPD) is an essential component of nursing, not least for the provision of safe and effective healthcare (Pool et al. 2013, Brekelmans, 2012). However, CPD is not the preserve of nursing and is equally important to professional development and practice in other health and social care professions. In the UK, the Health and Care Professions Council (HCPC) which is the regulatory body for a wide range of health and social care professions, describes CPD as:

“...a range of learning activities through which health and care professionals maintain and develop throughout their career to ensure that they retain their capacity to practice safely, effectively and legally within their evolving scope of practice." (HCPC, 2016)

This definition reflects the differing purposes of CPD such as the enhancement of professional practice, the promotion of safety and the facilitation of career development, an observation which is also made by Pool et al. (2013) in relation to a similarly multi-faceted definition of CPD by the American Nurses Association. Brekelmans et al. (2012) point out how, in the nursing literature, the terms CPD and continuing professional education (CPE) are often used interchangeably. However, Brekelmans et al. (2012) argue that CPD can be viewed as self-directed learning and may encompass a broad range of learning and development activities (many of which may be in the workplace) and CPE can be considered to be a component of CPD, relating more specifically to professionals engaging in formal educational provision. In a review of CPE in Ireland, Murphy et al. (2006) defines CPE in a similar way:

"CPE forms a significant element of CPD and comprises of a range of longer-term courses, focused on knowledge of a range of subject areas (or in some cases precise in-depth knowledge of one particular area), designed to provide participants with content-based expertise in a particular field. It may take the form of lecturers, guided reading and self-managed learning...leading to the awarding of a qualification upon completion". (p367)

As such, the provision of accredited CPE courses in Higher Education Institutions (HEI) for the health and social care workforce are only one means of facilitating CPD but, nevertheless, play a valuable role in enabling professionals to enhance knowledge and skills and to support career development. 
Continuing professional education: motivations and experiences of health and social care professional's part-time study in higher education. A qualitative literature review

For example, Cotterill-Walker (2011) undertook a review of the impact of master's level nurse education on patient care; nine quantitative and six qualitative studies were included in the review which identified positive gains for nurses in undertaking master's level education. These gains included professional and personal growth and increased confidence and critical thinking at work, although the evidence of clear benefits to patient care was inconclusive. Similarly, in a recent review of registered nurses' attitudes to post graduate education in Australia, Ng et al. (2014) found evidence of increased knowledge and skills as an outcome of postgraduate education, but little evidence of measured changes in practice. Cotterill-Walker (2011) argue that future research needs to measure the intended learning outcomes of master's level education against identifiable changes to patient care.

Whilst there is clearly a need to study the impacts of CPE on practice outcomes, arguably there is also a need to better understand how CPE is experienced and perceived by health and social care professionals. In focus groups that informed the Willis Commission's report on the future of nurse education in the UK (Health Education England and Nursing and Midwifery Council, 2015), some registered nurses expressed apprehension about the prospect of engaging in future study that would support their career progression. Moreover, in a recent Delphi study of nursing experts in the Netherlands exploring factors that influence nurses in participating in CPD, one of the key factors was the attractiveness of educational programmes (Brekelmans et al. 2016). Understanding more about perceptions with regard to motivations for - and experiences of - CPE may have implications for course design.

It is likely that health and social care professionals engaging in post registration HEI based CPE share some common characteristics, namely that: study will often be part-time and will usually take place alongside (often demanding) clinical practice; students are likely to be older than the majority of undergraduate cohorts; many will have additional commitments, such as families and mortgage repayments; and some professionals may have spent a significant length of time out of - or have not previously experienced - HEl education. In a survey of 70 qualified nurses and midwives in Ireland who were undertaking a part-time degree programme in nursing, Evans et al. (2007) identified common stressors affecting students; assignment completion/submission and balancing competing demands of work and family were top-most among these. Evans et al. concluded that the experiences and specific needs of qualified staff engaged in part-time HEl study are likely to be significantly different from fulltime, undergraduate nursing students. Interestingly, Swain and Hammond (2011) suggest there is a paucity of generic research on HEl students' experience where those students are both mature and part-time. 
Continuing professional education: motivations and experiences of health and social care professional's part-time study in higher education. A qualitative literature review

Bearing in mind the importance of CPD in modern health and social care and the significance of CPE as an element of this, and the shared characteristics of this particular group of students which may have specific educational and support needs, an understanding about the motivations and experiences of health and social care professionals accessing part time, HEI based CPE, is necessary. Such understanding is likely to inform how HEl programmes and employing organisations can best meet student needs to promote effective learning and support. The aim of this review, therefore, is to systematically explore the literature pertaining to the specific motivations and experiences of health and social care professionals who engage in part-time, accredited, CPE study in HEls.

\section{Methods}

The databases SCOPUS, Web of Science, OVID (Medline, PsychINFO and Social Policy and Practice) and CINAHL and the Cochrane Library were searched in December 2015. The search terms used are detailed in Table 1. In addition to databases, Google Scholar, and key journals were searched along with reference lists of the identified papers and papers that had cited these. No literature reviews specifically exploring this issue were identified.

\section{INSERT TABLE 1 ABOUT HERE}

\section{Inclusion criteria:}

- Studies that were qualitative in design or mixed (quantitative and qualitative) methods and having identifiable qualitative data. Qualitative data only was selected in order to focus on student experiences and perceptions

- Participants who were qualified health/social care professionals engaged in part- time, accredited HEl study while maintaining professional practice alongside their studies

- Studies exploring the motivations and/or experiences of/to study

- Papers published in English since 2000

\section{Exclusion criteria:}

- Studies that utilised quantitative methods where there was no identifiable qualitative component

- Studies where professionals had engaged in work-based or unaccredited CPD rather than HEI based accredited courses, or where this was unclear

- Studies in which students were engaging in full-time study or where this was unclear 
Continuing professional education: motivations and experiences of health and social care professional's part-time study in higher education. A qualitative literature review

- Studies focusing on how professionals had experienced change and/or development as a consequence of HEI post qualified study

- Studies examining the motivations and experiences of unqualified staff engaging in HEI based $\mathrm{CPE}$

\section{Quality Appraisal:}

All papers were published in peer reviewed journals. An appraisal tool developed by Elvish et al. (2013), appropriate for assessing the methodological quality of qualitative studies, was used to appraise the studies. The lead author (SB) and two other members of the writing team (HM and JK) independently applied the criteria, arriving at a consensus decision for each score. Studies were graded 0-3 against eight criteria (Table 2); the final scores are indicated in Table 3. Although the studies varied in methodological quality, none were excluded on these grounds for the purposes of this review.

\section{INSERT TABLES 2 AND 3 ABOUT HERE}

\section{Synthesis and analysis:}

A thematic analysis following the six-point method described by Braun and Clarke (2006) was followed. The analysis was led by the first author (SB) with the input of all members of the authorship and began with a familiarisation of the data in the identified papers. As argued by Thomas and Harden (2008), study results/findings, discussion and conclusions were all seen as providing valid data for analysis and these were included in the synthesis. Initial codes were generated according to content and meaning. The authors developed categories from the codes according to similarity and differences and from these, formulated themes. Two over-arching themes were identified: "motivations for accessing HEl education" and "experiences of study" and these in turn had sub-themes which are identified and discussed below.

\section{Results}

Combined searches produced 966 papers. These were reduced to 13 papers following removal of duplicates and applying inclusion/exclusion criteria (Figure 1). Decision-making on the selection of papers were agreed by all authors. Data was extracted from each study on the aims, methods, participants, key findings and location. The identified papers are summarised in Table 3. 
Continuing professional education: motivations and experiences of health and social care professional's part-time study in higher education. A qualitative literature review

\section{Theme 1: Motivations for accessing HEl education}

i) Personal and professional drivers

Spencer's (2006) qualitative study of 12 UK nurses, midwives and health visitors who had completed an MSc in Professional Practice, highlighted two types of motivation for undertaking postgraduate study which were classed as factors arising from the personal (internal) domain and factors related to the professional (external) domain. Personal factors included the desire to be personally and academically challenged, and professional (external) factors included pressures from the workplace to undertake study and the desirability of HEI study to advance career progression. Similarly, Watkins (2011) identified UK and German nurses who had completed a master's in Nursing Studies as "personal challenge seekers" and "professional challenge seekers"; the former group typified by nurses seeking an intellectual challenge or the desire for personal development and the latter group citing a variety of motivations including career advancement, not being "left-behind", increasing credibility and improving knowledge and skills to enhance practice.

These twin themes of personal and professional motivations featured in other studies. Participants in Richardson's (2010) study of New Zealand practice nurses, talked about wanting to "improve" themselves and gain in confidence and skills; students on an inter-professional master's degree in Sweden spoke of personal challenges and development (Olsson et al. 2013) while Jordanian nurses in Zahran's (2013) study were described as having a "drive for self-development". As with the study by Watkins (2011), broadening career opportunities featured in the studies by Zahran (2013) and Cooley (2008). Olsson et al's (2013) study also highlighted how some students explicitly expressed how the course would enable them to improve the quality of care and the majority of nurses in Watkins (2011) study applied to undertake the master's programme because they wanted to develop an understanding of research and the ability to use this to inform practice.

The one study that did not highlight clear personal and professional motivations for CPE as primary motivating factors was a UK study of nurses attending a course on the care of older people (Ellis and Nolan, 2005). Few of the 15 nurses who took part in the study had actually expressed a desire to attend the specific course. Selection for the course was described as "random" and "ad hoc" with places offered to nurses with little, if any, discussion about nurses' expectations or motivations.

ii) Influence of management and the availability of funding

The role of the workplace was cited in several studies as playing a crucial part in positively encouraging, or in discouraging, applications to engage in post registration HEl learning. Nurses in 
Continuing professional education: motivations and experiences of health and social care professional's part-time study in higher education. A qualitative literature review

Cooley's (2008) study generally found nurse management to be unsupportive and unlikely to encourage nurses to study. Practice nurses in Richardson and Gage's (2010) New Zealand study highlighted a process of negotiation with employers to secure management "buy in"; indeed, two practice nurses from the sample of 16 were so keen to engage in study that they part-funded the course themselves. Interestingly, Tame (2010), in a study of 23 preoperative nurses who had recently completed HEl study, found that three nurses had chosen to study 'in secret' without colleagues or management knowing. There were different influencing factors for those who studied secretly, but Tame (2010) suggests that what they shared in common was high levels of academic confidence and low levels of workplace support.

Perhaps unsurprisingly, the practical issues of funding and accessibility were highlighted in the literature (Watkins, 2011, Richardson and Gage, 2010). Full financial support to attend courses was described as a "massive reason why I have looked twice" by a practice nurse in Richardson and Gage's (2010) study. Similarly, financial support was a key motivator for a nurse in Cooley's (2008) study who stated: “The biggest one that motivated me was that it was going to be funded. I don't think I would have done it if it wasn't funded" (2008, p592).

\section{Theme 2: Experiences of study}

i) Adjusting to the academic requirements of HEl study

Apprehension and concern over a practitioner's own ability to engage in academic practice were highlighted in several studies. One of the interviewees in Illingworth et al. (2012) expressed how $s /$ he felt like 'a novice again' and had come close to leaving the course on several occasions; this was echoed by practice nurses in Richardson and Gage's (2010) study, who spoke of the "steep learning curve" in adjusting to academic requirements.

Greenwood et al. (2014) undertook a cross-sectional survey of post graduate students studying in a school of nursing and midwifery in Australia. The study focused on attitudes concerning referencing in academic work and the 244 respondents were asked "What have been the issues for you, if any, in meeting the standards of writing (including correct referencing) required at a university" (Greenwood et al. 2014, p450). Four themes were reported comprising: student confusion, relating to technical aspects of referencing; system related, where students found differing referencing styles and rules confusing; unintentional errors, where students complained about losing marks when making mistakes; and finally, academic related, where students found conflicting practices and expectations of lecturers problematic. There was a general lack of confidence in referencing and a 
Continuing professional education: motivations and experiences of health and social care professional's part-time study in higher education. A qualitative literature review

feeling of being inadequately prepared to meet the required standards of academic writing. Despite online resources being provided to help with referencing, few students reported using them.

Seventeen nurses in Johansen and Harding's (2013) study responded in writing to two open ended questions on essay-writing. Nurses experienced essay writing as challenging and time consuming and questioned the "fit" with their everyday working lives and clinical practice leading the authors to question the over-reliance on the essay format as a means of assessment. The authors acknowledged, however, that Norwegian students had traditionally written less at undergraduate level and the findings from this small sample of students may or may not translate to postgraduate nurses outside Norway.

In contrast to previous studies, nurses in the study by Illingworth et al. (2012) who were participating in $\mathrm{HEl}$ study for different specialist and advanced practice roles in the community, spoke in positive terms about HEl study, describing part-time university study as a "safe haven" from clinical practice in that it allowed space and time to think. Three of the four nurses who took part in follow-up interviews spoke of the significance of self-directed learning in master's level education, one nurse stating how: "... everybody would like to be hand fed but it is being supported but not hand fed that really helps with the development" (Illingworth et al. 2012, p341)

\section{ii) Balancing Competing Demands}

The impact of studying on family life was a key theme running across a number of the studies. Stanley (2003) interviewed nine professionals (comprising: nurses, midwives and health visitors) who had recently completed part-time modular pathways in an HEI. Participants described pressures of combining academic study with work, running a home and caring for children or relatives. Having less time for family or partners led to feelings of guilt and tension in relationships. Four of the participants in Spencer's (2006) study of 12 qualified nurses, midwives and health visitors who had enrolled upon a UK Master s programme in Professional Practice, felt there had been a negative impact on family life with one participant stating: "My kids wonder when they're going to get me back. My son asked me the other evening when I was going to stop reading my books and read one to him." (p50)

Cooley (2008) describes how two-thirds of the nurses in her study had dependents. Nurses had to organise child-care and family life to fit with the demands of the course. Studying could lead to tiredness and, as in Spencer (2006), there were expressions of guilt as study infringed on family time, one nurse stating: "I sometimes feel guilty and tired that I'm spending time studying and my children 
Continuing professional education: motivations and experiences of health and social care professional's part-time study in higher education. A qualitative literature review

are growing up very fast...And I sometimes say; 'I wonder should I be doing this?'” (Cooley, 2008 p592)

Employers varied in the support and time available for students to be released for academic courses. Stanley (2003) highlighted widespread inequality in the provision of study leave for those attending HEl study. Nicholl et al. (2014) in their study of practitioners on an inter-professional master's programme, found that students reported difficulties with work life balance with many attending university on their day off. Spencer (2006) also found variance in whether nurses attending master's study received study leave, and often where study leave was granted, nurses did not always experience a corresponding drop in workload.

A respondent in Spencer's study spells out that educational attainment can suffer as a consequence of the competing demands of work and family life and that expectations are re-adjusted accordingly: "I just... wish I could devote more time to it, because it's a compromise isn't it. You have to accept lower marks because you're balancing everything; you have to compromise with everything in your life" (Spencer, 2006, p49). This echoes the warning by Johansen and Harding (2013) who caution that when students are "time poor" due to competing demands, this may also have a bearing upon the quality of academic study and create a barrier to "deep" learning.

iii) Sources of support

Families in the studies by Stanley (2003) and Cooley (2008) were cited as being crucial in providing the necessary support to enable professionals to undertake part-time study. Workplaces were viewed as being either supportive or unsupportive depending on whether or not funding and study leave were made available (Cooley, 2008), and Ellis and Nolan (2005) highlighted the importance of effective managerial support. However, there was an absence in the literature regarding "best practice" concerning experiences of different approaches to teaching and learning in the HEI environment and the contribution this may, or may not, have made to a supportive and effective learning environment.

\section{Discussion}

Health and social care professionals have varied personal and professional motivations for undertaking part time HEI based CPE. Workplaces control external factors that can either create a climate that fosters and encourages CPE participation, or, conversely, may discourage professionals from applying 
Continuing professional education: motivations and experiences of health and social care professional's part-time study in higher education. A qualitative literature review

Only the studies by Greenwood et al. (2014) and Johansen and Harding (2013) specifically explored experiences of health and social care professionals in relation to pedagogic practice. These studies do at least raise questions for this body of students about the effectiveness, or suitability, of more traditional methods of teaching, learning and assessment, such as essay writing. It was not clear from the evidence whether such teaching and learning practices acted as motivators or barriers to participation in CPE; however, some professionals found engaging in these academic practices challenging and disconnected from work practice. Further research is clearly needed in this area.

A consistent finding in the evidence from this review was the challenges experienced by the competing demands of study, family and work, and the impact this can have on the lives and the academic performance of professionals. These findings support those of quantitative studies such as by Evans et al. (2007). The pedagogic concern, quite apart from any concerns over the wellbeing of practitioner students and their families/dependents, is that this may impact on the capacity of some students to engage in "deep learning" (Biggs and Tang, 2011). Unfortunately, there was no evidence in the review on how students managed these challenges or how different HEl teaching and learning approaches may have enhanced or exacerbated this.

The implications of the evidence presented in this review are that there is a need for HEls and health and social care employing organisations to better understand how professionals experience CPE, and what factors promote effective learning. In particular, HEls and employers need to explore effective means of minimising the potentially negative impacts for professionals engaging in part-time CPE with regard to juggling competing demands, and in doing so, foster effective learning, safe practice and the well-being of the professionals concerned. Specifically, research needs to focus on:

- A better understanding of how health and social care professionals juggle work, academic study and family life and the impacts of this on effective learning, safe practice and wellbeing

- The different ways in which professionals who are engaged in part-time CPE are supported via the workplace, the HEI, home, peer support and/or self-supporting strategies

- Understanding how innovative, flexible and/or supportive models of providing CPE are experienced by part-time professional students

The need to continue to develop and improve education and training for the health and social care workforce to meet emerging health and social care challenges is apparent. This is highlighted by the global challenge of meeting the needs of older people with multiple and complex conditions. For example, there are an estimated 46.8 million people living with dementia worldwide, and this is 
Continuing professional education: motivations and experiences of health and social care professional's part-time study in higher education. A qualitative literature review

expected to grow to 131.5 million by 2050 (Alzheimer's Disease International, 2015). In England, the need to develop the knowledge and skills of health and social care staff has been highlighted in recent policy statements (see for example: Department of Health, 2016). However, in order to provide the most effective education to address these needs, the evidence from this review is that, in addition to the need to focus on aligning the workforce to future work (Imison and Bohmer, 2014), there is also a need to align teaching, learning and assessment strategies to meet the specific needs of the staff/student group for whom HEI CPE brings particular challenges.

\section{Limitations}

There are limitations to this review. By focussing the search on peer-reviewed articles, other research that may be described as "grey-literature" may have been omitted. Additionally, the decision to focus on qualitative evidence may have excluded relevant findings from quantitative studies. Identifying appropriate key-words was challenging and the writing team quickly discovered that there is little consistency in the use of terminology to describe CPD/CPE and post registration education. Accordingly, search terms were set broadly and the search strategy of the lead author (SB) was checked by another members of the reviewing team (HM, HP, TB and JK), but it is still possible that relevant studies may have been overlooked.

\section{Conclusion}

There is a modest body of literature on the motivations of health and social care professionals who engage in part-time, accredited, HEI CPD and this reveals a combination of personal and professional motivations for study. When it comes to experiences of engaging in HEl based study, evidence indicates that staff frequently have to juggle the competing demands of study, family and work whilst making an often daunting transition to academic requirements of post registration, and often post-graduate level. There is some indication that the specific demands experienced by professionals in HEl study may impact on the quality and depth of learning. However, there is a need for further, and more robust, research to inform best practice with respect to HEI teaching, learning and assessment strategies. 
Continuing professional education: motivations and experiences of health and social care professional's part-time study in higher education. A qualitative literature review

\section{What is already known about this topic?}

- There is evidence of increased knowledge, skills and confidence of nurses and other health and social care professionals who have taken part continuing professional education (CPE)

- The impact of CPE to changes to practice and patient/client care is less conclusive

- There is a modest literature exploring the motivations for health and social care professionals to undertake Higher Education Institution (HEI) based CPE

\section{What this paper adds}

- Health and social care professionals are motivated to engage in part time HEI based CPE by a range of personal and professional factors

- Health and social care professionals who engage in part time HEI based CPE experience challenges in juggling competing demands of study, family and work and describe the negative impacts this can have on the quality and depth of learning

- A gap in the literature is revealed in relation to how different approaches to the delivery of $\mathrm{HEI}$ based CPE are experienced by health and social care professionals 
Continuing professional education: motivations and experiences of health and social care professional's part-time study in higher education. A qualitative literature review

\section{References}

Alzheimer's Disease International. 2015. The World Alzheimer's Report 2015: the global impact of dementia, an analysis of prevalence, incidence, costs and trends. Alzheimer's Disease International.

Biggs, J. and Tang, C. 2011. Teaching for quality learning at university. Maidenhead. Open University Press.

Braun, V. and Clarke, V. 2006. Using thematic analysis in psychology. Qualitative Research in Psychology.3 (2), 77-101.

Brekelmans, G., Maasen, S., Poell, R., Weststrate, J and Geudes, E. 2016 Factors influencing nurse participation in continuing professional development activities: survey results from the Netherlands. Nurse Education Today. 40. 13-19.

Brekelmans, G., Poell, R and van Wijk, K. 2012 Factors influencing continuing professional development: A Delphi study among nursing experts. European Journal of Training and Development. 37 (3), 313-325.

Clark, L., Casey, D., Morris, S. 2015. The value of Mdegrees for registered nurses. British Journal of Nursing. 24 (6), 28-34.

Cooley, M. 2008. Nurses' motivations for studying third level post-registration nursing programmes and the effects of studying on their personal and work lives. Nurse Education Today. 28, 588-594.

Cotterill-Walker, S. 2012. Where is the evidence that $\mathrm{M}$ level nursing education makes a difference to patient care? A literature review. Nurse Education Today. 32, 57-64.

Croisdale-Appleby, D. 2014. Re-visioning Social Work Education: An independent review. Available at: https://www.gov.uk/government/publications/social-work-education-review (Accessed 01/09/15).

Department of Health. 2016. The Prime Minister's Challenge on Dementia 2020: implementation plan. Department of Health. Available at: https://www.gov.uk/government/publications/challengeon-dementia-2020-implementation-plan (Accessed 13/07/2016).

Ellis, L., Nolan, M., 2005. Illuminating continuing professional education: unpacking the black box. International Journal of Nursing Studies 42 (1), 97-106.

Elvish, R., Lever, S-J., Johnstone, J., Cawley, R., Keady, J. 2013 Psychological interventions for carers of people with dementia: a systematic review of quantitative and qualitative evidence. Counselling and Psychotherapy Research. 13 (2), 106-12.

Evans, W., Timmins, F., Nichol, H., Brown, G. 2007. The impact of ongoing continuing professional development for nurses in the Republic of Ireland. Journal of Nursing Management. 15, 614-625.

Gigbels, H., O'Connell, R., Dalton-O'Connor, C., O'Donovan, M. 2010. A systematic review evaluating the impact of post-registration nursing and midwifery education on practice. Nurse Education in Practice. 10, 64-69. 
Continuing professional education: motivations and experiences of health and social care professional's part-time study in higher education. A qualitative literature review

Greenwood, M., Walkem, K., Mervyn-Smith, L., Shearer, T., Stirling, C. 2014. Postgraduate nursing student knowledge, attitudes, skills, and confidence in appropriately referencing academic work. Journal of Nursing Education. 53 (8), 447-452.

Health and Care Professions Council 2016 Available at: http://www.hcpc-uk.co.uk/registrants/cpd/ (Accessed 06/06/16).

Health Education England and Nursing and Midwifery Council 2015. Raising the Bar: shape of caring: a review of the future education and training of registered nurses and care assistants [Leeds]: HEE/NMC (Independent Chair: Lord Willis). Available at: http://hee.nhs.uk/wpcontent/blogs.dir/321/files/2015/03/2348-Shape-of-caring-review-FINAL.pdf (Accessed 01/09/15).

Illingworth, A., Aranda, K,. Goeas, S,. Lindley, P. 2012. Changing the way that I am: students experience of educational preparation for advanced nursing roles in the community. Nursing Education in Practice. 13, 338-343.

Imison, R., Bohmer C. 2014. NHS and social care workforce: meeting our needs now and in the future? The King's Fund.

Johansen, E., Harding, T., 2013. "So I forgot 1.5 line spacing! It doesn't make me a bad nurse!" The attitudes to and experiences of a group of Norwegian postgraduate nurses to academic writing Nurse Education in Practice 13, 366-370.

Mc Sweeny, F. 2014. "Moving In": Difficulties and support in the transition to higher education for in-service social care students. Social Work Education: the International Journal. 33 (3), 317-337.

Murphy, C., Cross, C and McGuire, D. 2006 The motivation of nurses to participate in continuing professional education in Ireland. Journal of European Industrial Training. 30, (5) 365-384.

Narey, M. 2014. Making the education of social workers consistently effective. Department for Education. Available at: https://www.gov.uk/government/publications/making-the-education-ofsocial-workers-consistently-effective (Accessed 01/09/15).

Ng, L., Tuckett, A., Fox-Young, S., Kain, V. 2014. Exploring registered nurses' attitudes towards postgraduate education in Australia: an overview of the literature. Journal of Nursing Education and Practice. 4 (2), 162-170.

Nicholl, H., Price, J., Tracey, C. 2014. An evaluation of an interprofessional Mlevel programme in children's palliative care. Part 1 the student's evaluation of the programme. Nurse Education in Practice. http://dx.doi.org/10.1016/j.nepr.2014.03.007.

Nursing and Midwifery Council 2015 The Code: professional standards of practice and behaviour for nurses and midwives. Available at: https://www.nmc.org.uk/globalassets/sitedocuments/nmcpublications/nmc-code.pdfhttps://www.nmc.org.uk/globalassets/sitedocuments/nmcpublications/nmc-code.pdf (Accessed 15/03/2016).

Olsson, M., Persson, M., Wikmar, L. 2013. Students' expectations when entering an interprofessional master's degree program for health professionals. Journal of Allied Health. 42 (1). 
Continuing professional education: motivations and experiences of health and social care professional's part-time study in higher education. A qualitative literature review

Pool, A., Poell, R and ten Cate T, 2013 Perspectives on age and continuing professional development for nurses: a literature review. Vocations and Learning. 6. 297-321.

Richardson, A. and Gage, J. 2010. What influences practice nurses to participate in post-registration education? Journal of Primary Health Care. 2 (2), 142-149.

Spencer, R. 2006. Nurses', midwives' and health visitors' perceptions of the impact of higher education on professional practice. Nurse Education Today. 26, 45-53.

Stanley, H., 2003. The journey to becoming a graduate nurse: a study of the lived experience of parttime post-registration students. 3, 62-71.

Swain, J. and Hammond, C. 2011. The motivations and outcomes of studying for part-time mature students in higher education International Journal of Lifelong Education. 30 (5), 591-612.

Tame, S. 2010. Secret study: a new concept in continuing professional education. Nurse Education Today. 31, 482-487.

Thomas, J. and Harden, A. 2008. Methods for the thematic synthesis of qualitative research in systematic reviews. BMC Medical Research Methodology. 8 (45), 1-10.

Watkins, D. 2011. Motivation and expectations of German and British nurses embarking on a master's programme. Nurse Education Today. 31, 31-35.

Zahran, Z., 2013. Master's level education in Jordan: a qualitative study of key motivational factors and perceived impact on practice. Nurse Education Today. 33, 1051-1056. 
Continuing professional education: motivations and experiences of health and social care professional's part-time study in higher education. A qualitative literature review

\section{Table 1: Search Terms}

AND

OR

Experience*

Attitude*

Perspective*

Motivation*
AND

OR

Nurs*

Interdisciplinary

Occupational Therap*

Physiotherap*

Allied Health Profession*

Social Work*

Continuing professional development

CPD

Continuing professional education 
Continuing professional education: motivations and experiences of health and social care professional's part-time study in higher education. A qualitative literature review

\section{Figure 1 Search and retrieval process}

Records identified through

database searching

$$
(n=931)
$$

Records identified through other search methods

$$
(n=35)
$$

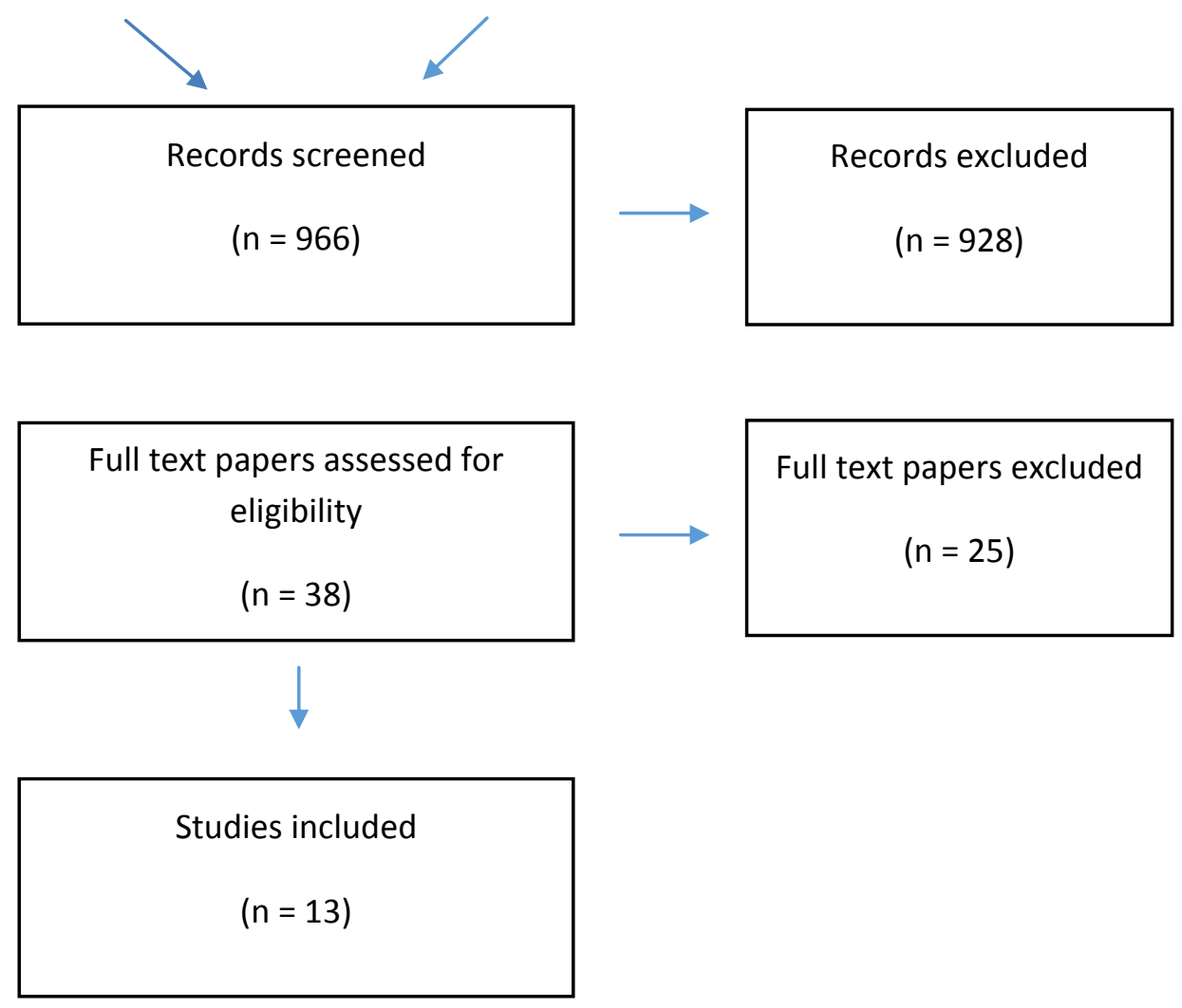


Continuing professional education: motivations and experiences of health and social care professional's part-time study in higher education. A qualitative literature review

\section{Table 2: Quality appraisal}

\section{Qualitative studies}

Design

Was the research design appropriate to address the aims of the research?

Sample

Data collection

Was the recruitment strategy appropriate to the aims of the research?

Were the data collected in a way that addressed the research issue?

Researcher relationship

Has the relationship between researcher and participants been adequately considered?

Ethics

Have ethical issues been taken into consideration?

Analysis

Was the data analysis sufficiently rigorous?

Findings

Is there a clear statement of findings?

How valuable?

How valuable is the research?

(Source: Elvish et al. 2013) 
Continuing professional education: motivations and experiences of health and social care professional's part-time study in higher education. A qualitative literature review

Table 3: Summary of studies

\begin{tabular}{|c|c|c|c|c|c|}
\hline $\begin{array}{l}\text { Author/ } \\
\text { year/ } \\
\text { country }\end{array}$ & Title & Methods & Participants & Findings & $\begin{array}{l}\text { Quality } \\
\text { score }\end{array}$ \\
\hline $\begin{array}{l}\text { Cooley } \\
(2008) \\
\text { Ireland }\end{array}$ & $\begin{array}{l}\text { Nurses } \\
\text { motivations for } \\
\text { studying third } \\
\text { level post } \\
\text { registration } \\
\text { nursing } \\
\text { programmes and } \\
\text { the effects on } \\
\text { studying on } \\
\text { personal and } \\
\text { work lives }\end{array}$ & $\begin{array}{l}\text { Qualitative: } \\
3 \text { focus groups }\end{array}$ & $\begin{array}{l}18 \text { qualified nurses } \\
\text { studying on post } \\
\text { registration diploma } \\
\text { and higher diploma } \\
\text { programmes. Nurses } \\
\text { had either never } \\
\text { previously studied } \\
\text { third-level post } \\
\text { registration } \\
\text { programmes or had } \\
\text { not done so in the } \\
\text { last five years }\end{array}$ & $\begin{array}{l}\text { Key themes: 1) "I want } \\
\text { to keep up and I want } \\
\text { to keep in there 2) "It's } \\
\text { about juggling and } \\
\text { keeping the balance 3) } \\
\text { "I'm looking at things } \\
\text { differently" }\end{array}$ & $10 / 24$ \\
\hline $\begin{array}{l}\text { Ellis and } \\
\text { Nolan } \\
\text { (2005) } \\
\text { UK }\end{array}$ & $\begin{array}{l}\text { Illuminating } \\
\text { continuing } \\
\text { professional } \\
\text { education: } \\
\text { unpacking } \\
\text { the black box }\end{array}$ & $\begin{array}{l}\text { An "instrumental } \\
\text { case study } \\
\text { approach" } \\
\text { involving } \\
\text { interviews with } \\
\text { practitioners } \\
\text { before, } \\
\text { immediately after } \\
\text { and 6-12 months } \\
\text { after completing } \\
\text { a course }\end{array}$ & $\begin{array}{l}15 \text { nurses who } \\
\text { undertook a post } \\
\text { qualified course on } \\
\text { meeting the needs of } \\
\text { older people ( } 21 \\
\text { managers were also } \\
\text { interviewed) }\end{array}$ & $\begin{array}{l}\text { Identifies a complex } \\
\text { array of factors } \\
\text { influencing outcomes } \\
\text { of education including } \\
\text { the selection } \\
\text { process, student } \\
\text { expectations and the } \\
\text { nature of the } \\
\text { educational } \\
\text { experience. }\end{array}$ & $12 / 24$ \\
\hline $\begin{array}{l}\text { Greenwood } \\
\text { et al. } \\
\text { (2014) } \\
\text { Australia }\end{array}$ & $\begin{array}{l}\text { Postgraduate } \\
\text { nursing student } \\
\text { knowledge, } \\
\text { attitudes, skills } \\
\text { and confidence in } \\
\text { appropriately } \\
\text { referencing } \\
\text { academic work }\end{array}$ & $\begin{array}{l}\text { Cross-sectional } \\
\text { survey including } \\
\text { open-ended } \\
\text { questions for } \\
\text { qualitative } \\
\text { responses }\end{array}$ & $\begin{array}{l}244 \text { school of nursing } \\
\text { and midwifery } \\
\text { students engaged in } \\
\text { a post graduate } \\
\text { programme at } \\
\text { certificate, diploma } \\
\text { and Master's level }\end{array}$ & $\begin{array}{l}\text { Four main themes } \\
\text { from the qualitative } \\
\text { data: } \\
\text { student confusion, } \\
\text { system related, } \\
\text { unintentional errors } \\
\text { and academic related. }\end{array}$ & $17 / 24$ \\
\hline $\begin{array}{l}\text { Illingworth et } \\
\text { al. (2013) } \\
\text { UK }\end{array}$ & $\begin{array}{l}\text { Changing the way } \\
\text { that I am: } \\
\text { students } \\
\text { experience of } \\
\text { educational } \\
\text { preparation for } \\
\text { advanced nursing } \\
\text { roles in the } \\
\text { community }\end{array}$ & $\begin{array}{l}\text { Qualitative: } \\
\text { Focus groups and } \\
\text { four 1:1 } \\
\text { interviews }\end{array}$ & $\begin{array}{l}15 \text { post registered } \\
\text { nurses studying on } \\
\text { different HEI courses } \\
\text { ( } 6 \text { at Master's level) } \\
\text { in preparation for } \\
\text { advanced roles in the } \\
\text { community }\end{array}$ & $\begin{array}{l}\text { Three themes } \\
\text { concerning the } \\
\text { preparation for } \\
\text { advanced roles in the } \\
\text { community: re- } \\
\text { inventing roles, re- } \\
\text { creating selves, re- } \\
\text { engaging with learning. }\end{array}$ & $14 / 24$ \\
\hline $\begin{array}{l}\text { Johansen and } \\
\text { Harding } \\
\text { (2013) } \\
\text { Norway }\end{array}$ & $\begin{array}{l}\text { "So I forgot to use } \\
1.5 \text { line spacing! It } \\
\text { doesn't make me } \\
\text { a bad nurse!": } \\
\text { The attitudes to } \\
\text { and experiences } \\
\text { of Norwegian } \\
\text { post graduate }\end{array}$ & $\begin{array}{l}\text { Qualitative } \\
\text { Written } \\
\text { responses to two } \\
\text { open-ended } \\
\text { statements on } \\
\text { academic writing }\end{array}$ & $\begin{array}{l}17 \text { nurses on a } \\
\text { "blended-learning" } \\
\text { post graduate course } \\
\text { in wound } \\
\text { management }\end{array}$ & $\begin{array}{l}\text { Participants had little } \\
\text { experience and were } \\
\text { challenged by } \\
\text { academic writing. } \\
\text { Traditional } \\
\text { assessments may be } \\
\text { creating barriers to } \\
\text { lifelong learning. }\end{array}$ & $10 / 24$ \\
\hline
\end{tabular}




\section{Continuing professional education: motivations and experiences of health and social care professional's part-time study in higher education. A qualitative literature review}

\begin{tabular}{|c|c|c|c|c|c|}
\hline & $\begin{array}{l}\text { nurses to } \\
\text { academic writing }\end{array}$ & & & & \\
\hline $\begin{array}{l}\text { Nicoll } \\
\text { (2014) } \\
\text { Ireland }\end{array}$ & $\begin{array}{l}\text { An evaluation of } \\
\text { an inter- } \\
\text { professional } \\
\text { Master's level } \\
\text { programme in } \\
\text { children's } \\
\text { palliative care. } \\
\text { Part } 1 \text { the } \\
\text { students' } \\
\text { evaluation of the } \\
\text { programme }\end{array}$ & $\begin{array}{l}\text { Questionnaire for } \\
\text { predominantly } \\
\text { quantitative } \\
\text { feedback but with } \\
\text { additional open } \\
\text { ended questions } \\
\text { inviting feedback } \\
\text { on the } \\
\text { programme }\end{array}$ & $\begin{array}{l}15 \text { students } \\
\text { (comprising nurses, } \\
\text { social workers, } \\
\text { physiotherapists and } \\
\text { chaplains) who had } \\
\text { participated in three } \\
\text { modules }\end{array}$ & $\begin{array}{l}\text { Strengths, } \\
\text { dissatisfactions and } \\
\text { ways forward were } \\
\text { highlighted }\end{array}$ & $12 / 24$ \\
\hline $\begin{array}{l}\text { Olsson et al. } \\
\text { (2013) } \\
\text { Sweden }\end{array}$ & $\begin{array}{l}\text { Students' } \\
\text { expectations } \\
\text { when entering an } \\
\text { interprofessional } \\
\text { Master's degree } \\
\text { programme for } \\
\text { health } \\
\text { professionals }\end{array}$ & $\begin{array}{l}\text { Qualitative } \\
\text { Questionnaire } \\
\text { with open ended } \\
\text { questions }\end{array}$ & $\begin{array}{l}42 \text { participants from } \\
6 \text { professions } \\
\text { (physiotherapy, } \\
\text { nursing, occupational } \\
\text { therapy, social work, } \\
\text { dietetics and a } \\
\text { biomedical analyst) }\end{array}$ & $\begin{array}{l}\text { Four categories of } \\
\text { expectations: } \\
\text { increased professional } \\
\text { competence, enhanced } \\
\text { interprofessional } \\
\text { collaboration, personal } \\
\text { development and } \\
\text { increase quality of } \\
\text { patient care }\end{array}$ & $6 / 24$ \\
\hline $\begin{array}{l}\text { Richardson } \\
\text { and Gage } \\
\text { (2010) } \\
\text { New Zealand }\end{array}$ & $\begin{array}{l}\text { What influences } \\
\text { practice nurses to } \\
\text { participate in } \\
\text { post-registration } \\
\text { education? }\end{array}$ & $\begin{array}{l}\text { Qualitative: } \\
\text { Focus group } \\
\text { interviews }\end{array}$ & $\begin{array}{l}16 \text { practice nurses } \\
\text { engaged in post } \\
\text { registration } \\
\text { education at } \\
\text { graduate }(n=10) \text { and } \\
\text { post graduate }(n=6) \\
\text { levels }\end{array}$ & $\begin{array}{l}\text { Seven key themes: } \\
\text { Motivations to learn, } \\
\text { enablers for learning, } \\
\text { challenges to accessing } \\
\text { education, negotiating } \\
\text { with the employer, } \\
\text { changing clients, } \\
\text { changing role of the } \\
\text { practice nurse, vision } \\
\text { as a practice nurse. }\end{array}$ & $16 / 24$ \\
\hline $\begin{array}{l}\text { Spencer } \\
(2006) \\
\text { UK }\end{array}$ & $\begin{array}{l}\text { Nurses', } \\
\text { midwives' and } \\
\text { health visitors' } \\
\text { perceptions of } \\
\text { the impact of } \\
\text { higher education } \\
\text { on professional } \\
\text { practice }\end{array}$ & $\begin{array}{l}\text { Semi structured } \\
\text { interviews }\end{array}$ & $\begin{array}{l}12 \text { nurses, midwives } \\
\text { and health visitors }\end{array}$ & $\begin{array}{l}\text { Four themes emerged } \\
\text { from the interview } \\
\text { data. One was } \\
\text { concerned with } \\
\text { personal and } \\
\text { professional } \\
\text { motivations to } \\
\text { undertake study, the } \\
\text { remaining three } \\
\text { related to the impact } \\
\text { on practice. }\end{array}$ & $18 / 24$ \\
\hline $\begin{array}{l}\text { Stanley } \\
\text { (2002) } \\
\text { UK }\end{array}$ & $\begin{array}{l}\text { The journey to } \\
\text { becoming a } \\
\text { graduate nurse: a } \\
\text { study of the lived } \\
\text { experience of } \\
\text { part-time post- } \\
\text { registration } \\
\text { students }\end{array}$ & $\begin{array}{l}\text { Qualitative: } \\
\text { Taped, } \\
\text { unstructured } \\
\text { interviews }\end{array}$ & $\begin{array}{l}9 \text { nurses who had } \\
\text { recently completed a } \\
\text { part-time post } \\
\text { registration modular } \\
\text { nursing degree } \\
\text { programme }\end{array}$ & $\begin{array}{l}\text { Experiences were } \\
\text { symbolised as a } \\
\text { journey. A “complex } \\
\text { web of variables" are } \\
\text { described influenced } \\
\text { by the individual, the } \\
\text { workplace, managers } \\
\text { and colleagues and } \\
\text { personal tutor. } \\
\text { Personal and } \\
\text { professional changes } \\
\text { were often stressful }\end{array}$ & $14 / 24$ \\
\hline
\end{tabular}


Continuing professional education: motivations and experiences of health and social care professional's part-time study in higher education. A qualitative literature review

\begin{tabular}{|c|c|c|c|c|c|}
\hline & & & & $\begin{array}{l}\text { and support networks } \\
\text { were utilised. }\end{array}$ & \\
\hline $\begin{array}{l}\text { Tame } \\
\text { (2010) } \\
\text { UK }\end{array}$ & $\begin{array}{l}\text { Secret study: a } \\
\text { new concept in } \\
\text { continuing } \\
\text { professional } \\
\text { education }\end{array}$ & $\begin{array}{l}\text { Qualitative: } \\
\text { unstructured } \\
\text { interviews }\end{array}$ & $\begin{array}{l}23 \text { preoperative } \\
\text { nurses who had } \\
\text { recent experience of } \\
\text { university-based } \\
\text { study }\end{array}$ & $\begin{array}{l}\text { Two themes: "public } \\
\text { study" where nurses } \\
\text { told all colleagues they } \\
\text { were studying and } \\
\text { "secret study" where } \\
\text { nurses did not inform } \\
\text { colleagues }\end{array}$ & $17 / 24$ \\
\hline $\begin{array}{l}\text { Watkins } \\
\text { (2011) } \\
\text { UK and } \\
\text { Germany }\end{array}$ & $\begin{array}{l}\text { Motivations and } \\
\text { expectations of } \\
\text { German and } \\
\text { British nurses } \\
\text { embarking on a } \\
\text { Master's } \\
\text { programme }\end{array}$ & $\begin{array}{l}\text { Qualitative: } \\
\text { 1:1 semi } \\
\text { structured } \\
\text { interviews }\end{array}$ & $\begin{array}{l}10 \text { German and } 9 \text { UK } \\
\text { nurses who had } \\
\text { completed an MSc in } \\
\text { Nursing Studies }\end{array}$ & $\begin{array}{l}\text { Two types of } \\
\text { applicants with } \\
\text { differing motivations } \\
\text { were identified: } \\
\text { personal challenge } \\
\text { seekers and } \\
\text { professional challenge } \\
\text { seekers }\end{array}$ & $14 / 24$ \\
\hline $\begin{array}{l}\text { Zahran } \\
\text { (2013) } \\
\text { Jordan }\end{array}$ & $\begin{array}{l}\text { Master's level } \\
\text { education in } \\
\text { Jordan: a } \\
\text { qualitative study } \\
\text { of key } \\
\text { motivational } \\
\text { factors and } \\
\text { perceived impact } \\
\text { on practice }\end{array}$ & $\begin{array}{l}\text { Qualitative } \\
\text { Semi-structured } \\
\text { interviews }\end{array}$ & $\begin{array}{l}10 \text { Master's level } \\
\text { nurses (plus } 27 \text { and } \\
\text { other practitioners } \\
\text { and managers from } \\
\text { the settings in which } \\
\text { the nurses worked) }\end{array}$ & $\begin{array}{l}\text { Four main themes: } \\
\text { self-development, } \\
\text { broadening career } \\
\text { opportunities, } \\
\text { developing practice } \\
\text { and the perceived } \\
\text { impact of Master's } \\
\text { level nurses on } \\
\text { practice }\end{array}$ & $10 / 24$ \\
\hline
\end{tabular}

